\title{
The Same but Different: Regulating Zero Hours Work in Two Liberal Market Economies
}

Research Article

Lorraine Ryan, Juliet MacMahon, Michelle O'Sullivan, Thomas Turner, Jonathan Lavelle, Caroline Murphy, Mike O’Brien, Patrick Gunnigle

University of Limerick, Limerick, Ireland

Abstract: The rise in zero hours contracts in liberal market economies (LMEs) has recently received much attention with calls for regulation to protect workers. LMEs typically adopt flexible labour market policies that are less regulated than coordinated market economies (CMEs) as a competitive advantage. In this paper we examine nuanced differences in the nature and regulation of zero hours work in the United Kingdom (UK) and Ireland. With an increased diffusion of zero hours work in both countries, we examine the different responses taken by these similar LMEs to this contemporary employment issue. We examine whether, as expected in an LME context, there is weak regulation in both countries and the factors influencing this. We find subtle but important differences between regulations of zero hours contracts. We conclude by discussing the possible implications of the UK's exitfrom the European Union (EU) (Brexit) for the regulation of precarious work.

Keywords: Zero Hours Contracts; Legal Regulation; Liberal Market Economy; Employment Relationship; Precarious Work.

(c) Sciendo

\section{INTRODUCTION}

International human resource management (IHRM) faces many challenges and an understanding of the legal regulation of the employment relationship in different countries is important for firms operating in a global capacity. Different human resources $(H R)$ issues come to the fore at different times depending on economic and market conditions, trends in HRM, trade union strength and political imperatives. Issues around precarious work have received much attention in a number of liberal market economies (LMEs) in recent years (Barnard, 2014; McCann, 2014). Within the varieties of capitalism literature, Ireland and the United Kingdom (UK) are typically categorised as LMEs and draw their competitive advantage from flexible labour market policies and 'light touch' regulation (Hall and Soskice, 2001). Both Ireland and the UK are highly internationalised economies and (Ireland in particular) rely on labour market flexibility to attract foreign direct investment (FDI) (Lavelle et al., 2009). In both these countries zero hours contracts have recently come under scrutiny by trade unions, academics, politicians and the media. Zero hours contracts, sometimes referred to as on-call work, typifies work where there are no guaranteed hours offered by the employer. Internationally, across the United States (US), New Zealand and other countries, the apparent rise in zero hours contracts has received much (mostly negative) attention (Kalleberg, 2009; Lambert, 2008). Trade unions, academics, workers, politicians and public opinion have been critical of zero hours contracts in the main viewing them as exploitative, contributing to underemployment and precarity and undermining citizenship (Pickavance, 2014; Standing, 2014; USDAW, 2014). A number of MNCs such as McDonalds, Abercrombie and Fitch and Sports Direct have been the subject of media and law enforcement attention over their use of such contracts (Pickavance, 2014). A key debate is therefore currently underway around the apparent increased use of zero hours contracts, whether they should be regulated further and what form and content such regulation would assume (Adams et al., 2015; CIPD, 2013). This has prompted governments in many countries including the UK and Ireland to focus attention on the issue.

However, a critical difficulty in studying and indeed regulating zero hours contracts is the definitional uncertainty surrounding the term. 'Zero hours contracts' have become synonymous with precarious work but the term is often 
used to describe a range of different forms of work such as part-time work, casual work, low hours and on-call work. Indeed Adams et al. (2015:2) note that the zero hours contract label 'serves as no more than convenient shorthand for masking the explosive growth of precarious work for a highly fragmented workforce'. This lack of clarity hinders cross-country comparisons, which are important for researchers and policy makers. Hence, we find it is more appropriate to use the term zero hours work which we consider as work where there are no guaranteed hours. This encapsulates more accurately the reality of contemporary employment practices and overcomes some of the problems associated with the strict legal definition of a zero hours contract.

Employers argue that zero hours work provides the necessary flexibility required by organisations and are often welcomed by workers due to the flexibility they offer and provide many benefits. However, trade unions and other organisations highlight the negative impact this type of precarious work has on workers such as unpredictable hours and pay and a lack of entitlement to rights under existing protective legislation (Adams et al., 2015; Unison, 2014). Thus, there has recently been lobbying of government in both the UK and Ireland with calls for regulation to better protect workers from these negative effects. This renewed focus on zero hours work has drawn increased attention to the legal standing of such contracts and the rights of employees and obligations of employers and indeed governments in this regard. Yet the core of an LME is efficiency of the market facilitated in the labour market by the absence of regulations such as minimum wages, employment laws and trade unions that are seen to inhibit the flexible use of labour (Hyman, 2008). However, the deregulation of labour markets as well as other state policies such as privatisation and outsourcing has been a driver of precarious jobs (Carré et al., 2012; Kalleberg, 2012; Prosser, 2016). These policies adopted in LMEs in pursuit of enhanced economic performance are a result of the increased interdependence of economic activities in the global economy and, in the case of EU countries, Europeanisation. The implications of this increased interdependence are significantly mediated by institutions and policymaking structures of nation states (Gallie, 2017). The contribution of this paper lies in drawing out the similarities and differences between two LMEs, Ireland and the UK in relation to regulation of zero hours work and exploring whether the different institutional and policy responses mediate the impact of zero hours work on workers.

The paper is structured as follows. We begin by drawing on precarious work literature to highlight the impact of zero hours work practices on workers (Burgess et al., 2013; Kalleberg, 2012). Next, we examine workplace flexibility and how LMEs facilitate zero hours work. Following an outline of the research approach, we give an overview of the legal and industrial relations contexts of both countries, highlighting the similarities and differences between the two. Our findings then examine the nuanced but important differences in the responses to calls for regulation of zero hours contracts in both the UK and Ireland. We discuss the factors from the national contexts that might be expected to account for these differences and conclude by reflecting on the potential implications of Brexit on UK labour regulation and the consequent implications for Ireland.

\section{PRECARIOUS WORK}

While precarious work is not a new phenomenon, the concept is coming under increased scrutiny in recent times given the polarisation of dual labour markets and expansion of different forms of work facilitated by digitisation, deregulation and globalisation. Contemporary studies highlight concerns around the growth and normalisation of precarity as a feature of current employment (Allmendinger et al., 2013; Broughton et al., 2016). The erosion of the standard employment relationship (SER) in favour of atypical forms of work combined with changing labour force demographics and compounded by the impact of economic crises are but some of the explanations for the expansion of precarious work across Europe (Bosch, 2004; Fudge, 2017; Prosser, 2016). Precarious work is subject to definitional uncertainty but generally refers to what Kalleberg (2009:2) describes as 'employment that is uncertain, unpredictable and risky from the point of view of the worker'. Precarious work can be found in both standard and non-standard forms of employment (Grimshaw et al., 2016) which erodes the quality of work and the norms of good employment. Precarious work is often characterised by low income, limited social benefits and statutory entitlements (Vosko, 2010).

The consequences of increased precarious work have been examined from a number of perspectives. These include the impact on workers particularly marginalised labour market groups (Campbell and Price, 2016; Howcroft and Rubery, 2018); the extent to which the state and institutional frameworks facilitate such work (Carré et al., 2012; Gautie et al., 2010; Hyman, 2008; O'Sullivan et al., 2017) and the implications for the erosion of individuals' rights 
and citizenship (Standing, 2014; Ryan et al., 2019a; Turner, 2016). Concomitantly there has been much debate around how best to approach the regulation of precarious work to improve employment and social protection for all (Adams and Deakin, 2014; Grimshaw et al., 2016; Rubery, 2015). It is to this debate that this paper seeks to add.

Within the realm of precarious work, zero hours work has recently become a high profile topic of debate in the UK and Ireland. Zero hours work appeared to increase significantly in the UK in recent years. The Chartered Institute for Personnel Development (CIPD) noted increases in the numbers reported to be working zero hours (from 250,000 employees in 2012 according to the Office for National Statistics (ONS), to an estimate of 1 million in 2013, and subsequently 697,000 according to the ONS in 2014). Since then, there has been a further rise with the most recent estimate by the ONS in December 2018 putting the number of workers on such contracts in their main job at 844,000, representing 2.6 per cent of all people in employment (ONS, 2019). It must be noted however, that much of the apparent increase is likely to have been affected by greater awareness of such contracts given media coverage and high profile disputes with companies such as Sports Direct and McDonalds (Walsh, 2013). The numbers are nonetheless significant and prompted public debate and political lobbying in the UK.

A report commissioned by the Irish Government found little evidence of zero hours contracts in Ireland. However, it found $5.3 \%$ of workers in Ireland work 'constantly variable hours'. This is the nearest possible quantitative measurement to capture those on zero hours type work in Ireland (O'Sullivan et al., 2015). Furthermore qualitative data demonstrated a growing concern among trade unions and Non-Government Organisations (NGOs) in relation to a growth in zero hours type work (labelled If and When contracts). While more accurate data on the true extent of zero hours work is necessary in both countries, there is nonetheless compelling evidence that this form of work is increasing. Zero hours contracts in both the UK and Ireland are prevalent in accommodation/food, health/social work and wholesale/retail sectors, and are also in transport/arts/other services. As these sectors tend to be female dominated, higher percentages of women are on zero hours contracts than men (Adams et al., 2015; Moore et al., 2018). Higher proportions of younger age groups work on zero hours contracts and research has pointed to insecurity of income and low hours (Adams and Deakin, 2014).

Generally, those employed on zero hours work arrangements are subject to poor terms and conditions of employment. Unpredictability around the number and scheduling of hours and the consequent impact on pay is a key concern (Adams and Deakin, 2014; Lambert, 2008; Rubery et al., 2015; Wood, 2016). While some workers with no guaranteed hours may earn high pay, zero hours work is precarious because its outcomes, in the main, include low pay, job insecurity and very limited social and employment rights protection (Blanchflower et al., 2017; Broughton et al., 2016; Eurofound, 2015). Workers face difficulties accessing financial credit, lack of input into scheduling of work hours and contracts which do not reflect the reality of hours worked (Kalleberg, 2009; USDAW, 2014). Problems managing work and family life arise due to insufficient notice when called to work and/or being sent home during a shift. Further, although zero hours contracts usually stipulate that workers are entitled to decline work, studies in the UK and Ireland have shown that in practice individuals feel pressured to accept any work they are offered as they believe they will be penalised by their employer for not accepting work (Broughton et al., 2016; O'Sullivan et al, 2015; Unison, 2014).

\section{Labour Market Policies}

These difficulties are compounded by problems in other areas such as childcare and social welfare support (Moore et al., 2018). Childcare has a major bearing on the impact of zero hours work on women and the family. CMEs are more likely to provide social goods such as childcare and to pursue policies that limit precarious work to achieve social justice (O'Sullivan et al., 2015). However, in LMEs particularly the UK and Ireland childcare is typically subject to competition of the market resulting in the highest childcare costs in the Organisation for Economic Co-operation and Development (OECD) countries as represented by percentage of net household income at 46 per cent (UK) and 30 per cent (Ireland) in 2018 (OECD, 2019). This is an important policy area for governments and greater support in the form of childcare subsidies or tax breaks for childcare costs would lessen some of the negative impact of zero hours work for many workers, particularly women.

In the context of the UK Brinkley (2013) suggests that a combination of light employment regulation, less generous welfare and more stringent criteria for accessing welfare have contributed to higher levels of employment in the UK. In Ireland commentators have also suggested that liberal market policies facilitating zero hours work are good for employment overall. Indeed Government welfare policies reducing employer's social insurance contributions after the global financial crisis were directly aimed at job creation and improving labour cost competitiveness (O'Sullivan et al., 2017). However, critics of the liberal market approach to precarious work note that workers can become 
trapped in precarious jobs if left unregulated. International bodies such as the OECD have argued that 'good quality' jobs are necessary for sustainable and inclusive growth and workers' well-being (OECD, 2016). At EU level, one of the core principles of the new European Pillar of Social Rights is around quality of work and employment (European Commission, 2017a). This may have implications for regulation of precarious work in the future in both these countries.

\section{ZERO HOURS AND WORKPLACE FLEXIBILITY}

In a globally competitive market, the need for flexibility is crucial for many businesses, particularly with more service and demand led sectors (Atkinson, 1984; Gouliquer, 2000). LMEs are expected to have weak statutory regulation that enables flexible labour markets (Hall and Soskice, 2001). However, the absence of strong statutory regulation either through employment law or institutional support for collective bargaining has significant implications for workers particularly those employed in precarious work. Indeed, there is a considerable body of literature that examines the relationship between neo-liberalism and work precarity (Lea, 2013; Standing, 2014; Turner, 2016). It is broadly accepted that there is a growing cohort of workers characterised by job insecurity, short-term contracts, lack of rights at work and often, low pay (Lea, 2013). The apparent rise in zero hours work in Ireland and the UK in recent decades has drawn attention to the need for regulation to protect such workers. Workers on zero hours contracts are arguably the most vulnerable of precarious workers and most in need of regulation (Adams et al., 2015).

Employers have claimed zero hours contracts have been labelled unfairly as precarious work when in fact they have many benefits for both employers and workers (Ryan et al., 2019b). The seasonal nature of tourism for example requires flexibility especially with business peaking during the summer. Changes in consumer patterns in the retail sector require longer opening hours and more evening and weekend work. In sectors characterised by predominantly female employment, for example health, flexibility is often necessary to accommodate workers' caring responsibilities. Certain groups in the labour market such as women, students and older people may not want or have the opportunity for full-time employment. Indeed, flexible work arrangements such as overtime, part-time work, flexi-time, and atypical employment contracts have long been used by firms (Reilly, 2001). Workers and trade unions have sought and embraced many flexible work options that can improve work-life balance and give greater scope for atypical workers to participate in the labour market (Gerstel and Clawson, 2001). Zero hours work however primarily garners criticism as employers reap the benefits of flexibility and workers suffer from unpredictability and lack of employment rights (Adams et al., 2015; Osborne and Duncan, 2016; UNISON, 2014). There is also a fear among commentators that zero hours work is spreading. Far from being contained to the realm of student work and casual Saturday jobs, zero hours work seems to be replacing previously full time, relatively secure permanent jobs in sectors such as health, education and academia (Kalleberg, 2009; Maguire, 2017). Indeed there is a growing unease that precarity, in the form of uncertain and volatile jobs, is becoming the new norm of work. It is important to note there is a growing body of literature that suggests even within CMEs institutional protections for workers (such as collective bargaining) are weakening and flexibilisation of employment is increasing. Liberalisation, Europeanisation and the expanding global economy have challenged traditional CME models increasing pressure on employers to adopt practices considered typical of LMEs (such as zero hours work) and national institutions to facilitate this, thus increasing susceptibility to work precarity (Baccaro and Pontusson, 2016; Crouch, 2006; O'Sullivan et al., 2019; Streeck, 2009). Uncertainty and precarity in the labour market can have serious repercussions for employers and workers with reduced terms and conditions of employment, difficulties retaining quality staff, increased industrial conflict and overall deterioration of employment relationships. This is why there have been recent efforts to examine the extent of zero hours work in the UK and Ireland and evaluate the impact of such work on employees. Prosser (2016) notes that OECD data on employment protection support the view of the UK and Ireland as particularly deregulated labour markets. In this paper, we test the assumption of the varieties of capitalism literature that precarious work is weakly regulated in these two LMEs. We focus on zero hours work as this form of precarious work is currently very topical in both countries, having recently been subject to specially commissioned government reports. We also extricate the differences in regulation of such work in these two countries by examining the impact of national contexts. 


\section{RESEARCH APPROACH}

For this paper, we draw primarily on data collected by the authors as part of a wider report commissioned by the Irish Government and completed in 2015. Analysis of macro level data from the Irish Quarterly National Household Survey (QNHS) (Central Statistics Office) was conducted. For the UK comparison, we utilised secondary data including data from the ONS. Secondly we carried out a review of case law in Ireland and the UK pertaining to the issues of employment status as it relates to zero hours work. The shared history and development of jurisprudence in both common law jurisdictions allows for this cross comparative analysis on the issue of employment status. Finally we conducted a macro level review using content analysis of secondary data in the form of government debates, inquiries and reports (see for example O'Sullivan et al., 2015; Pickavance, 2014) in both countries surrounding proposed responses to the regulation of zero hours which provided insights into the nuanced impact of specific factors particularly political, social and institutional factors. When all three strands of research were integrated they provided a basis for our analysis.

\section{IRELAND AND THE UK: ZERO HOURS WORK AND EMPLOYMENT STATUS}

Ireland and the UK present an interesting case from an industrial relations and employment regulation point of view given their historical context. Until the early $20^{\text {th }}$ century Ireland was part of the British Empire and as such formed part of the British legal jurisdiction. After the enactment of the Irish constitution in 1932 Ireland began to enact legislation in the employment sphere in its own right. However an enduring legacy of Ireland's pre 1932 relationship with the UK is both a common law system and a body of subsequent case law which still informs Irish jurisprudence. Employment regulation in both the UK and Ireland is also currently (pre-Brexit) influenced by membership of the EU and commitments to deliver legislation as a result of various Directives relating to employment such as equality and working time. Whilst Member States have some level of individual discretion in implementing Directives legislatively, this system gives rise to some similarities in protective employment legislation in both jurisdictions.

Irelands' industrial relations system post-independence was influenced initially by historical connections with the UK but development was subsequently shaped by the specific political, economic, institutional and cultural context of Ireland as it developed as an independent sovereign state. A crucial difference between the two countries was the era of national level co-ordinated social partnership in Ireland which enjoyed surprising longevity from 1987 for over two decades (Teague and Donaghey, 2009). Despite an absence of institutional complementarities, (typically associated with CMEs) Ireland sustained tri-partite industrial relations arrangements during a period of sustained economic growth. Trade unions at national level during this period enjoyed input into social and economic policies including the regulation of work. Therefore while there are many similarities between both these LMEs given their shared history, we examine whether developments within the national contexts have moderated institutional responses to issues around zero hours work.

A key issue emanating from shared common law and jurisprudence in both Ireland and the UK, which impacts on the regulation of zero hours work is that of employment status. This is not a new issue with case law dating back to the 1800 s when Ireland and the UK were one legal jurisdiction. In fact, questions around employment status are currently an issue across a number of countries particularly given the emergence of new forms of work in the globalised economy. In many countries, including the UK and Ireland someone must be classified as an employee to access most employment rights and social welfare entitlements. For this reason, there has been a plethora of legal cases by workers disputing their employment status including Deliveroo riders in the UK, Uber and Lyft drivers in the US, UK and in the European Court of Justice, Citysprint couriers and Excel cycle couriers in UK, Vabu couriers in Australia and Handy house cleaners in the US (Warren, 2016). The basic principle of employment status is that a person is either an independent contractor or an employee. Common to both the UK and Ireland is a body of case law which has determined that an independent contractor will not normally be covered by much of the protective employment legislation that has been enacted in both jurisdictions (Cox et al., 2009, Freedland, 2003; 2006) such as that relating to unfair dismissal, redundancy, working time, maternity protection and others.

The stumbling block for those seeking access to the employment status of employee has in recent times been the 'test for mutual obligation'. Broadly speaking this test examines the extent to which the employer has contracted into an obligation to provide work and the worker has an obligation to perform that work. The leading UK case of 
Carmichael and Leese vs National Power plc ${ }^{1}$ is a useful example. In this case tour guides were employed on a zero hours basis. The reality of the situation was that they regularly worked on average up to 25 hours a week and rarely, if ever, refused work offered. The House of Lords however found that there was an absence of an 'irreducible minimum of mutual obligation' to create a contract of service. Thus the plaintiffs were held not to be employees and were outside the scope of protective legislation. Similarly the 2008 Irish case of Minister for Agriculture and Food vs Barry and Ors ${ }^{2}$, drawing on UK jurisprudence, gave a very clear indication of the centrality of the mutuality of obligation condition for an employment contract to exist in the Irish context where Edwards $\mathrm{J}$ stated:

'The requirement of mutuality of obligation is the requirement that there must be mutual obligations on the employer to provide work for the employee and on the employee to perform work for the employer. If such mutuality is not present, then either there is no contract at all or whatever contract there is must be a contract for services or something else, but not a contract of service ... If there is no mutuality of obligation it is not necessary to go further. Whatever the relationship is, it cannot amount to a contract of service'.

In both the UK and Ireland employers have successfully argued that those working on a zero hours basis are not de facto 'employees' and thus are outside the scope of much of the protective legislation. This is because zero hours type work is characterised by the use of contracts containing clauses stating the employer is under no obligation to provide work and the individual is under no obligation to accept. Similarly clauses are often inserted to indicate that the individual may provide a substitute when they are not available, implying there is no obligation on the individual to provide their personal service. These clauses, often termed 'boilerplate clauses' have proved a difficult barrier for zero hours workers to surmount in both jurisdictions notwithstanding the willingness of courts in both jurisdictions to 'look behind' such clauses to seek to establish the real nature and thus legal basis of the working relationship (see for instance recent Irish cases: Ticketline Trading as Ticketmaster $v$ Sarah Mullen ${ }^{3}$ and Contract Personnel Marketing Ireland vs Marie Buckley ${ }^{4}$ and UK cases such as Pimlico Plumbers Limited and Charlie Mullins vs Gary Smith ${ }^{5}$ and Dewhurst vs Citysprint UK ${ }^{6}$.

\section{LEGISLATIVE REPONSES TO ZERO HOURS WORK IN THE UK AND IRELAND}

In this paper we set out to examine whether these two countries weakly regulate zero hours work as expected given their status as LMEs. Contemporary research on varieties of capitalism, whilst acknowledging the broad similarities between LMEs, acknowledges that the concept of an LME is an ideal type and that the level of coordination around market mechanisms is moderated /mediated by national context in terms of policy regimes, industrial relations structures and actors (Gallie, 2017; Hall 2015). Here we examine both countries' reactions to triggers for a legislative response with respect to zero hours work. In Ireland legislation was first introduced in 1997, as a response to a European level working time Directive: Directive 93/104/EC. This legislation, The Organisation of Working Time Act 1997 was a broad Act governing working time in general. Analysis of historical records of media and parliamentary debates on the drafting of the working time legislation clearly shows the influence brought to bear by various actors such as opposition politicians, unions and employer organisations. The drafting of the legislation coincided with negotiations between social partners on a new national wage agreement in 1996 in which the Irish Congress of Trade Unions (ICTU) demanded that employment legislation be reviewed in light of the growth of atypical work as a condition of agreement. In response to unions' concerns, the Organisation of Working time Act 1997 was drafted to include a clause which at the time purported to address the issue of zero hours work. However records of parliamentary debates show that employers' representatives successfully sought to exclude casual workers from the application of the Act.

The clause (in Section 18 of the Act) confers an entitlement to compensation if the employer does not require a person employed on a zero hours contract to work in a given week where they are required to be available. They are entitled to compensation amounting to $25 \%$ of the time they were required to be available or 15 hours pay, whichever is the lesser. Significantly, Section 18 continues to state that there must be a 'requirement' of an employee to be available to work.

\footnotetext{
1 Carmichael and Leese v National Power plc [1999] ICR 1226 (HL)

2 Minister for Agriculture and Food v Barry and Ors [2008] IEHC 216

3 Labour Court, Ticketline trading as Ticketmaster v Sarah Mullen DWT1434 10 th April 2014

42011 Contract Personnel Marketing Ireland vs Marie Buckley (DWT1145)

5 [2017] EWCA Civ 51

6 ET2202512/2016
} 
This section applies to an employee whose contract of employment operates to require the employee to make himself or herself available to work for the employer in a week ... and the said requirement is not one that is held to arise by virtue only of the fact, if such be the case, of the employer having engaged the employee to do work of a casual nature for him or her'. (Extract from Section 18)

Given that Section 18 includes the words 'contract of employment' and 'require' and excludes work of a 'casual nature' it has been held by the Irish Courts to exclude workers who do not satisfy the test for mutual obligation. Thus a 'zero hours contract' is very narrowly defined in Irish legislation. It is clear from research in Ireland (Grogan, 2014; McMahon et al., 2017) that zero hours work where employers have inserted aforementioned boilerplate clauses to sidestep any mutuality (and thus obligations under the Act) is utilised in certain sectors. Effectively the absence of mutuality means that hours can fluctuate from no hours to a number of hours in a given week. The available work can vary from day-to-day, week-to-week and month-to-month. The period between assignments can also vary. The practical outcome of this is that whilst the Irish State has regulated to deal with a form of zero hours work, the wording of the legislation is such that it renders very weak protection for the majority of those working on an on call/ casual or zero hours basis.

Prior to the 1990s the UK had a similar 'binary divide' of employee and independent contractor as Ireland still currently has. In response to the increasing heterogeneity of work arrangements a number of additional categories were introduced by Parliament, mostly notably the 'worker' concept (Adams et al., 2019). Those that come under this category are entitled to a smaller set of employment rights, such as minimum wage, working time and health and safety protection than 'employees', and so are excluded from rights such as unfair dismissal, sickness, maternity and redundancy pay. This means that even where individuals working some form of zero hours fail to establish employee status in the UK, they may still be able to access employment rights available to those on a 'worker' contract (Adams et al., 2019). As in Ireland the concept of mutuality of obligation in establishing status is central. Claiming employee or worker status is, as Adams et al. (2019) note however, only the first hurdle in claiming employment rights. Establishing continuity of service necessary to claim many employment protection rights can also prove difficult for zero hours workers.

In the UK in 2013, as a result of widespread public concern over the reported rise of zero hours work, the issue became the subject of a Government consultation (BIS, 2013), a report commissioned by the Labour Party, and a private member's Bill proposing to confer a wider range of rights on zero hours workers. Analysis of parliamentary debates, media reports and House of Commons (lower house of Parliament) Research briefings highlighted the attempts by stakeholders to influence the shape and extent of proposed legislation. For instance employers' groups such as the Confederation of British Industry (CBI) and the Institute of Directors (loD) argued that such contracts were necessary for maintaining low levels of unemployment and were an attractive proposition for many workers (Trotman, 2015), whilst the Labour party called for a ban on zero hours contracts and the Trades Union Congress (TUC) called for a redefinition of employment status or at least a right to regular hours after a period of time (TUC, 2014).

Proposed legislation was drawn up by the Government in 2014 (clause 139 of the Small Business, Enterprise and Employment Bill 2014) and was largely limited to banning the use of exclusivity clauses (provisions which stipulate that an employee is contractually prohibited from working for a second employer). Attempts by Labour MPs to introduce more far reaching provisions were voted down. The ensuing legislation has been described as minimalist by various commentators (The Guardian, 2015) in that it failed to address many of the issues highlighted by unions, NGOs and legal experts around zero hours work. The key issue for many zero hours workers in the UK (as highlighted by recent cases) is one of employment status, access to employment protection legislation and certainty of hours, rather than the issue of exclusivity clauses. Furthermore it is arguable that the reality of zero hours work and the unpredictability of scheduling of hours prevents workers making themselves available to other employers, regardless of exclusivity clauses, thus a ban on such achieves little in the way of extended rights. Table 1 below outlines the key differences and similarities between zero hours work in Ireland and the UK highlighting the possible impact of the national contexts.

\section{Contemporary Developments}

The renewed focus on zero hours work in Ireland in recent years offered a number of possible options for new regulation. The recent Government report showed that the legislative approach within the Organisation of Working Time Act 1997 was insufficient as zero hours contracts within the meaning of that Act are not extensive in Ireland yet different forms of zero hours work are spreading. However, despite proposals from opposition parties, trade unions 
and NGOs for legislation which would protect workers who fall foul of the current employment status condition, the outcome of the national debate was for the centre right Fine Gael Government to introduce the Employment (Miscellaneous Provisions) Act 2018. Although lauded as 'one of the most significant changes to working conditions in a generation' and purporting to outlaw zero hours work in all but a few circumstances, contemporary commentary suggests that the new Act 'looks set to change precisely nothing' and in fact 'might be imperilling workers it intended to protect' (McMahon and Dundon, 2019). This is because the wording of the new Act specifically excludes from its protection those zero-hours workers whose job tasks are classified as 'casual' and therefore critically does not address the problem of employment status and mutuality of obligation. The new legislation provides some welcome rights for low hours employees (such as a right to request being placed on a particular band of weekly working hours if they have been regularly working that amount for 12 months). However, failure to address the employment status issue may have 'a perverse paradoxical effect by incentivising employers to downgrade people's rights through the use of contracts with non-mutuality clauses. This embeds insecurity for those the new 2018 Act may have been intended to protect' (McMahon and Dundon, 2019).

Table 1: Types of Contracts: UK and Ireland

\begin{tabular}{|c|c|c|c|c|}
\hline \multirow[b]{2}{*}{ Country } & \multicolumn{2}{|l|}{ Zero Hours Work } & \multirow[b]{2}{*}{ Key Legislative Regulations } & \multirow[b]{2}{*}{$\begin{array}{c}\text { Influence of National } \\
\text { Context }\end{array}$} \\
\hline & Practice & $\begin{array}{l}\text { Employment } \\
\text { Status }\end{array}$ & & \\
\hline \multirow[t]{2}{*}{ Ireland } & $\begin{array}{c}\text { Zero Hours Contract where } \\
\text { person has a contract of } \\
\text { employment }\end{array}$ & Employee & $\begin{array}{l}\text { Section } 18 \text { of } 1997 \text { Organisation } \\
\text { of Working time Act. Entitlement to } \\
\text { compensation } \\
\text { Section } 18 \text { amended by the } \\
\text { Employment (Miscellaneous } \\
\text { Provisions) Act } 2018 \text {. Increased } \\
\text { entitlement to compensation. }\end{array}$ & $\begin{array}{l}\text { Pressure brought to bear by } \\
\text { trade unions to legislate in } 1997 \\
\text { under social partnership, Equally } \\
\text { this pressure was moderated by } \\
\text { pressure from employers groups } \\
\text { resulting in exclusion of casual } \\
\text { on call contracts from effects of } \\
\text { legislation. }\end{array}$ \\
\hline & $\begin{array}{l}\text { On call contracts where } \\
\text { there is a 'boilerplate } \\
\text { clause' emphasising lack } \\
\text { of contractual mutuality of } \\
\text { obligation in the relationship }\end{array}$ & Non-employee & $\begin{array}{l}\text { None. These workers have been } \\
\text { found to be outside the scope of } \\
\text { much of the protective legislation } \\
\text { New legislation remains to be tested } \\
\text { but indications are such workers will } \\
\text { continue to be unprotected. }\end{array}$ & $\begin{array}{l}\text { Recent pressure from trade } \\
\text { unions, NGOs and left wing } \\
\text { political parties to introduce } \\
\text { more robust legislation to include } \\
\text { these workers. Opposition from } \\
\text { employer groups. }\end{array}$ \\
\hline UK & Zero hours on call contracts & $\begin{array}{l}\text { Disputed. Can } \\
\text { be deemed a } \\
\text { 'worker' or in } \\
\text { more infrequent } \\
\text { cases an } \\
\text { 'employee' by the } \\
\text { courts. Otherwise } \\
\text { treated as an } \\
\text { independent } \\
\text { contractor with } \\
\text { no access to } \\
\text { legislative rights }\end{array}$ & $\begin{array}{l}\text { Section } 130 \text { of the } 1996 \text { Employment } \\
\text { Rights Act defines the 'employee' } \\
\text { and 'worker' categories. } \\
\text { The Small Business Enterprise and } \\
\text { Employment Act } 2015 \text { banning the } \\
\text { use of exclusivity clauses. A dismissal } \\
\text { for breaching an exclusivity clause } \\
\text { will be deemed automatically unfair } \\
\text { regardless of length of service. }\end{array}$ & $\begin{array}{l}\text { In public and parliamentary } \\
\text { debates leading up to the drafting } \\
\text { and passing of the legislation } \\
\text { more wide ranging and robust } \\
\text { measures were proposed. There } \\
\text { was strong opposition from } \\
\text { employer groups such as the } \\
\text { Confederation of British industry } \\
\text { (CBI) and the institute of Directors } \\
\text { to legislation that would extend } \\
\text { employment status and enhanced } \\
\text { to zero hours workers beyond a } \\
\text { ban on exclusivity clauses. The } \\
\text { legislation finally introduced by } \\
\text { the Tory/liberal coalition limited } \\
\text { protection to a ban on exclusivity } \\
\text { clauses. }\end{array}$ \\
\hline
\end{tabular}

\section{DISCUSSION AND CONCLUSION}

Precarious work is an important international employment issue particularly in the aftermath of the global financial crisis as both employers and employees find themselves operating in more competitive and uncertain contexts (Broughton et al., 2016). Drivers of precariousness include privatisation, outsourcing and increasingly deregulated labour markets directed towards labour market flexibility, cost efficiencies and competitive advantage. While these drivers are intensified by globalisation, Europeanisation and the resultant push for competitiveness it is arguable that the institutional framework of national contexts can exert an influence on the risk of precariousness. In this paper, we set out to examine the differences between two seemingly similar countries, both typically classified as LMEs in their responses to zero hours work. Ireland has sometimes been classified as an atypical LME due, in part 
to the enduring legacy of social partnership (Schneider and Paunescu, 2012). It might thus be expected that there would be stronger protection for employees in this jurisdiction given the influence at national level of trade unions in 1997 when legislation was first drafted and enacted. However the outcome to date (as evidenced by the case law) is weak regulation with minimal protection for zero hours workers and commentators have questioned the extent to which the new Act will improve security and predictability of working hours for such workers. Thus while there are nuanced differences between legislation governing zero hours work in both the UK and Ireland the responses of both countries are still firmly rooted in a liberal market perspective. The bottom line in both jurisdictions is that people working on a zero hours basis remain outside the scope of most protective legislation. Workers in both countries employed on zero hours work arrangements are engaged in precarious work and are subject to the same negative impacts of such work. To borrow from an Asian phrase, zero hours work in the two LMEs of the UK and Ireland is the 'same, same but different'.

Some commentators have suggested (Collins et al., 2012; Freedland, 2006) that the only meaningful way to provide robust legislative provision to combat precarious work resulting from such casualization of employment status is to redefine the fundamental tests used for determining status. Freedland (2006) presents the idea of simplifying the issue around a single concept such as a 'personal employment nexus', whereby all rights would effectively accrue to those people who currently come within the UK definition of worker: i.e. they undertake to perform the work personally for the employer. However there appears to be little political appetite in either jurisdiction to interfere with the common law principles to this extent. Other recommendations include expanding collective bargaining rights and avoiding any changes to the legislative framework thus devolving the regulation of the employment relationship to industry or firm level. This of course would involve a more robust recognition of collectivism which may also be opposed by employer representatives.

In Ireland we see some evidence of this firm level regulation with the emergence of 'banded hours' contracts in the retail sector. A number of unionised retail companies such as Tesco, Penneys (Primark), Marks and Spencer and SuperValu have introduced this form of flexible work. Typically banded hours agreements are collectively agreed with a trade union and the new legislation in Ireland provides rights for workers to request to be placed in a higher band of hours. Banded hours place each employee within a set guaranteed 'band' of hours e.g. 15-19 hours. Following a periodic review any employee who continuously works above the band they are in, is automatically lifted into the next band (i.e. the higher number of hours that they have actually been working now becomes their new guaranteed band). Most banded hours agreements offer a choice to workers who might wish to stay on their existing arrangement. Banded hours agreements still provide significant flexibility for employers as they typically exclude peak and trough trading periods from calculations of weekly average hours and allow employers to move employees to lower minimum bands during the quieter months of January and February. The banded hours agreements give guarantees in relation to the number but not the scheduling of hours (Murphy et al., 2019). In Ireland this form of 'regulation' has heretofore been confined to unionised environments whereas new legislative provisions are more comparable to CME countries such as the Netherlands, where employees are legally entitled to a guaranteed number of hours once they have been regularly working that number of hours for a particular period of time. However current indications are that overall this legislation may be just as weak as recent legislation in the UK with regard to zero hours workers. Indeed labour politicians had criticised the proposed new legislation before it was enacted claiming it 'does nothing at all to provide a remedy for thousands of workers' engaged in zero hours work (Miley, 2018).

The onset of Brexit poses some interesting questions for the level of similarity or potential divergence between these two LME's in the future. Ireland will continue to be part of the EU and as such must remain committed to transposing certain Directives into Irish legislation whereas it is currently unclear what impact Brexit will have on the regulation of the labour market in the UK. A Directive on Transparent and Predictable Working Conditions in the EU has recently been proposed to address the increasingly diverse regulatory systems across the EU which 'increase the risk of competition based on undercutting social standards'. This, it is argued 'has harmful consequences also for employers, who are subject to unsustainable competitive pressure, and for Member States, who forego tax revenue and social security contributions' (European Commission, 2017b). Of crucial significance for zero hours workers is that the scope of the Directive will be clarified by defining the notion of 'worker' based on established case-law of the Court of Justice of the European Union (CJEU) for determining worker status, and extended by reducing the possibilities for Member States to exclude workers in short or casual employment relationships (European Commission, 2017b). If this occurs then there is potential for better protection of zero hours workers in Ireland in the future given the influence this will have on the national context. The outcome of Brexit will shape 
the regulation of zero hours work in the UK. As the global economy slowly emerges from the effects of the Global Financial Crisis, and European and other institutions focus on restoration of quality of work this is an important area for future research.

\section{References}

Adams, A., Adams, Z. and Prassl, J. (2019). 'Legitimising Precarity: Zero Hours Contracts in the United Kingdom', in M. O'Sullivan, J. Lavelle, J. McMahon, L. Ryan, C. Murphy, T. Turner and P. Gunnigle (eds), Zero Hours and On-Call Work in Anglo-Saxon Countries, Singapore: Springer.

Adams, A., Freedland, M. and Prassl J. (2015). The Zero Hours Contract: Regulating Casual Work or Legitimising Precarity? University of Oxford Legal Research Paper Series, Paper No. 00/2015.

Adams, Z. and Deakin, S. (2014). Reregulating Zero Hours Contracts, Liverpool: The Institute of Employment Rights.

Allmendinger, J., Hipp, L. and Stuth, S. (2013). 'Atypical Employment in Europe 1996-2011' Discussion Paper No. P 2013-003, Berlin, WZB.

Atkinson, J. (1984). Manpower strategies for flexible organizations, Personnel Management, August, 28-31.

Baccaro, L. and Pontusson, J. (2016). 'Rethinking comparative political economy'. Politics \& Society, 44: 2, 175-207.

Barnard, C. (2014). 'Non Standard Employment; What Can the EU Do?' Keynote paper, European Labour Law Network. 7th Annual Legal Seminar, New Forms of Employment and EU law, 27-28 November, The Hague, Netherlands.

BIS, (2013) Employment Status Review, December 2013. https://www.gov.uk/government/publications/ employment-status-review-2015 [Accessed 11 June, 2019].

Blanchflower, D., Costa, R. and Machin, S. (2017). The Return of Falling Real Wages. Working Paper, LSE Centre for Economic Performance, London.

Bosch, G. (2004). 'Towards a New Standard Employment Relationship in Western Europe'. British Journal of Industrial Relations, 42: 4, 617-636.

Brinkley, I. (2013). 'Flexibility or insecurity? Exploring the rise in zero hours contracts', London: The Work Foundation.

Broughton, A., Green, M., Rickard, C., Swift, S., Eichhorst, W., Tobsch, V., Magda, I., Lewandowski, P., Keister, R., Jonaviciene, D., Ramos Martin. N.E., Valsamis, D. and Tros, F. (2016). Precarious Employment in Europe: Patterns, Trends and Policy Strategies. Brussels: European Parliament.

Burgess, J., Connell, J. and Winterton, J. (2013).
'Vulnerable workers, precarious work and the role of trade unions and HRM'. The International Journal of Human Resource Management, 24: 22, 4083-4093.

Campbell, I. and Price, R. (2016). 'Precarious work and precarious workers: Towards an improved conceptualisation'. The Economic and Labour Relations Review, 27: 3, 314-332.

Carré, F., Findlay, P., Tilly, C. and Warhurst, C. (2012). 'Job quality: Scenarios, analysis and interventions', in C. Warhurst, F. Carré, P. Findlay and C. Tilly (eds), Are Bad Jobs Inevitable? Basingstoke: Palgrave Macmillan.

CIPD. (2013) Zero Hour Contracts: Myth and Reality. London: CIPD

Collins, H., Ewing, K.D. and McColgan, A. (2012). Labour Law, Cambridge, Cambridge University Press.

Cox, N., Corbett, V. and Ryan, D. (2009). Employment Law in Ireland, Dublin: Clarus Press.

Crouch, C. (2006). 'Diversity in employment patterns in North-West Europe: A regional and sectoral approach', in J. Beckert, B. Ebbinghaus, A. Hassel and M. Philip (eds), Transformationen des Kapitalismus, Festschrift für Wolfgang Streeck zum sechzigsten Geburtstag.

Eurofound (2015) New forms of employment. www. eurofound.europa.eu/sites/default/files/ef publication/field_ef_document/ef1461en.pdf [Accessed 11 June, 2019].

European Commission (2017a). Concluding report. Social Summit for Fair Jobs and Growth. Gothenburg: European Commission and Government Offices of Sweden.

European Commission (2017b). Proposal for a Directive of the European Parliament and of the Council on transparent and predictable working conditions in the European Union, Brussels, European Commission. https://eur-lex.europa.eu/ legal-content/EN/TXT/?uri=CELEX:52017PC0797 [Accessed 11 June, 2019]

Freedland, M. (2003). The Personal Employment Contract, Oxford: Oxford University Press.

Freedland, M. (2006). 'From the Contract of Employment to the Personal Work Nexus', Industrial Law Journal, 35: 1, 1-29.

Fudge, J. (2017). 'The Future of the Standard 
Employment Relationship: Labour Law, New Institutional Economics and Old Power Resource Theory', Journal of Industrial Relations, 59: 3, 374-392.

Gallie, D. (2017). 'The Quality of Work in a Changing Labour Market', Social Policy and Administration, 51: 2, 226-243.

Gautié, J., Westergaard-Nielsen, N., Schmitt, J. and Mayhew, K. (2010) 'The impact of institutions on the supply side of the low-wage labor market', in J. Gautié and J. Schmitt (eds), Low-Wage Work in the Wealthy World, New York: Russell Sage Foundation.

Gerstel, N. and Clawson, D. (2001). 'Unions' Responses to Family Concerns', Social Problems, 48: 2, 27797.

Gouliquer, L. (2000). 'Pandora's Box: The Paradox of Flexibility in Today's Workplace', Current Sociology, 48: 1, 29-38.

Grimshaw, D., Johnson, M., Rubery, J. and Keizer, A. (2016). Reducing precarious work: protective gaps and the role of social dialogue in Europe. http://www.research.mbs.ac.uk/ewerc/Portals/0/ Documents/Comparative-Report-ReducingPrecarious-Work-v2.pdf [Accessed 11 June, 2019].

Grogan, R. (2014), The Practical Aspects of Presenting and Defending Working Time Claims from a Practitioners Perspective. Paper presented at Joint Seminar Southern Law Association and Employment Law Association of Ireland, Cork, 28 November.

Hall, P.A. (2015). Varieties of Capitalism, Emerging Trends in the Social and Behavioral Sciences: An Interdisciplinary, Searchable, and Linkable Resource, Wiley Online. 15 MAY 2015 DOI: 10.1002/9781118900772.etrds0377

Hall, P.A. and Soskice, D. (2001). Varieties of Capitalism: The Institutional Foundations of Comparative Advantage, Oxford: Oxford University Press.

Howcroft, D. and Rubery, J. (2018). 'Gender equality prospects and the fourth industrial revolution', in M. Neufeind, J. O'Rielly, and F. Ranft (eds), Work in the digital age: Challenges for the fourth industrial revolution, London: Rowman \& Littlefield.

Hyman, R. (2008). 'The state in industrial relations', in P. Blyton, E. Heery, N. Bacon and J. Fiorito (eds), The Sage Handbook of Industrial Relations, London: Sage.

Kalleberg, A.L. (2009). 'Precarious Work, Insecure Workers: Employment Relations in Transition', American Sociological Review, 74: 1, 1-22.

Kalleberg, A.L. (2012). 'Job Quality and Precarious Work: Clarifications, Controversies, and Challenges',
Work and Occupations, 39, 427-448.

Lambert, S.J. (2008). 'Passing the buck: Labor flexibility practices that transfer risk onto hourly workers', Human Relations, 61: 9, 1203-1227.

Lavelle, J., McDonnell, A. and Gunnigle, P. (2009). Human Resource Practices in Multinational Companies in Ireland: A Contemporary Analysis, Dublin: Government Publications.

Lea, J. (2013). 'From Denizen to Citizen and Back: Governing the Precariat through Crime', Criminal Justice Matters, 93:1, 4-5.

Maguire, P. (2017). 'Casual contracts: the precarious world of academia; Colleges are turning to private firms to hire temporary staff. Is this the end of job security at third-level?' The Irish Times, Tuesday, April $4^{\text {th }}$.

McCann, D. (2014). 'Equality through precarious work regulation: lessons from the domestic work debates in defence of the Standard Employment Relationship', International Journal of Law in Context, 10: 4, 507-521.

McMahon, J., O’Sullivan, M., Turner, T., Ryan, L., Lavelle, J., Murphy, C., O’Brien, M. and Gunnigle, P. (2017). 'Zero Hours Work and the Role of the Law in Ireland", in K. Ahlberg and N. Bruun (eds) The New Foundations of Labour Law, Frankfurt, Germany: Peter Lang.

McMahon, J and Dundon, T. (2019) 'Just when you thought it was safe to sign a zero hours contract' Irish Times, April 25. https://www.irishtimes.com/ business/work/just-when-you-thought-it-wassafe-to-sign-a-zero-hours-contract-1.3855957 [Accessed 11 June, 2019].

Miley, I. (2018). 'Labour says legislation will not protect 'if and when' workers' RTE News, Feb 13. https:// www.rte.ie/news/ireland/2018/0213/940394employment-contracts/ [Accessed 11 June, 2019].

Moore, S., Tailby, S., Antunes, B. and Newsome, K. (2018). 'Fits and fancies': the Taylor Review, the construction of preference and labour market segmentation', Industrial Relations Journal, 49: 5-6, 403-419.

Murphy, C., Lavelle, J., Turner, T., Ryan, L., McMahon, J., O'Sullivan, M., O'Brien, M. and Gunnigle, P. (2019). 'Zero Hours Work in Ireland' in M. O'Sullivan, J. Lavelle, J. McMahon, L. Ryan, C. Murphy, T. Turner and P. Gunnigle (eds), Zero Hours and On-Call Work in Anglo-Saxon Countries, London: Springer.

Office for National Statistics (ONS) (2019). People in employment on zero hours contracts. https://www.ons.gov.uk/ employmentandlabourmarket/peopleinwork/ employmentandemployeetypes/datasets/ 
emp17peopleinemploymentonzerohourscontracts [Accessed 11 June, 2019].

Organisation for Economic Co-operation and Development (OECD) (2016). New data show importance of quality as well as quantity of jobs and how both evolved during crisis. https://www. oecd.org/g20/topics/employment-and-socialpolicy/the-crisis-has-had-a-lasting-impact-on-jobquality-new-oecd-figures-show.htm [Accessed 22 May 2019].

Organisation for Economic Co-operation and Development (OECD) (2019). Net childcare cost for parents using childcare. https://stats.oecd.org/ Index.aspx?DataSetCode=NCC [Accessed 11 June, 2019].

Osborne, H. and Duncan, P. (2016). 'Number of care workers on zero hours contracts jumps to one in seven'. The Guardian $17^{\text {th }}$ November 2016. https:// www.theguardian.com/uk-news/2016/nov/17/careworkers-zero-hours-contracts-unison-minimumwage [Accessed 11 June, 2019].

O'Sullivan, M., Turner, T., McMahon, J., Ryan, L., Lavelle, J., Murphy, C., O'Brien, M and Gunnigle, P. (2015). A Study of the Prevalence of Zero Hours Contracts among Irish Employers and its Impact on Employees. Dublin: Department of Jobs, Enterprise and Innovation, November.

O'Sullivan, M., Turner, T., Lavelle, J., McMahon, J. Murphy, C., Ryan, L., Gunnigle, P. and O'Brien, M. (2017). 'The role of the state in shaping zero hours work in an atypical liberal market economy' Economic and Industrial Democracy, https://doi. org/10.1177/0143831X17735181

O'Sullivan, M., Turner, T., McMahon, J., Ryan, L., Lavelle, J., Murphy, C., and Gunnigle, P. (2019). Zero Hours and On-Call Work in Anglo-Saxon Countries, London: Springer.

Pickavance, N. (2014). Zeroed Out: The place of zerohours contracts in a fair and productive economy, London: Labour Party.

Prosser, T. (2016). 'Dualization or liberalization? Investigating precarious work in eight European countries', Work, Employment and Society, 30: 6, 949-965.

Reilly, P.A. (2001). Flexibility at work: Balancing the interests of employer and employee, Gower Publishing Ltd.

Rubery, J., Grimshaw, D., Hebson, G. and Ugarte, S.M. (2015). 'It's all about time': Time as contested terrain in the management and experience of domiciliary care work in England', Human Resource Management, 54: 5, 753-772.

Rubery, J. (2015). Reregulating for Inclusive Labour
Markets, Conditions of Work and Employment Series No. 65. Geneva: International Labour Organisation (ILO).

Ryan, L., McMahon, J. and Turner, T. (2019a). 'Between the profit imperative and worker welfare: Can responsible companies stem the expansion of precarious work?', in M. O'Sullivan, J. Lavelle, J. McMahon, L. Ryan, C. Murphy, T. Turner and P. Gunnigle (eds), Zero Hours and On-Call Work in Anglo-Saxon Countries, London: Springer.

Ryan, L., Lavelle, J., MacMahon, J., O'Sullivan, M., Turner, T., Murphy, C., O’Brien, M. and Gunnigle, P. (2019b). 'Defining and Regulating Zero Hours Work: Lessons from a Liberal Market Economy' Nordic Journal of Working Life Studies, 9:5, 75-93.

Schneider, M.R. and Paunescu, M. (2012) 'Changing varieties of capitalism and revealed comparative advantages from 1990 to 2005: A test of the Hall and Soskice claims', Socio-Economic Review, 10: 4, 731-753.

Standing, G. (2014). A Precariat Charter: From Denizens to Citizens, London: Bloomsbury.

Streeck, W. (2009). Re-Forming Capitalism: Institutional Change in the German Political Economy, Oxford: Oxford University Press.

Teague, P. and Donaghey, J. (2009). 'Why has Irish social partnership survived?', British Journal of Industrial Relations, 47: 1, 55-78.

The Guardian (2015), 'Tories' legislation to protect zerohours workers called 'toothless' by lawyers' The Guardian, 27 May. https://www.theguardian.com/ uk-news/2015/may/26/conservatives-zero-hourscontracts-small-business-act-david-camerontoothless [Accessed 11 June, 2019].

Trades Union Congress (2014). Ending the Abuse of Zero Hours Contracts: YUC response to BIS Consultation, Equality and Employment Rights Department, London: TUC.

Trotman, A. (2015). 'Zero hours contracts save UK from Eurozone levels of unemployment', The Telegraph, 25 Feb. http://www.telegraph.co.uk/ finance/jobs/11435789/Zero-hours-contractssave-UK-from-eurozone-levels-of-unemployment. html [Accessed 11 June, 2019].

Turner, B.S. (2016). 'We are all denizens now: on the erosion of citizenship', Citizenship Studies, 20: 6-7, 679-692.

Union of Shop, Distributive and Allied Workers (USDAW) (2014). Zero Hours and Short Hours Contracts ADM, USDAW Executive Council.

UNISON (2014). Zero Hours Contracts in the NHS. https://www.unison.org.uk/motions/2014/health/ zero-hours-contracts-in-the-nhs/ [Accessed 11 
June, 2019].

Vosko, L. (2010). Managing the Margins: Gender, Citizenship, and the International Regulation of Precarious Employment, Oxford: Oxford University Press.

Walsh, F. (2013) 'Up to $90 \%$ of staff ineligible for scheme that saw retailer hailed as 'model employer' The Irish Times August 7. https://www.irishtimes.com/ business/retail-and-services/up-to-90-of-staffineligible-for-scheme-that-saw-retailer-hailed-as- model-employer-1.1486447 [Accessed 11 June, 2019].

Warren, L. (2016). 'Uber, Lyft and others must have rules or workers will lose out' The Guardian, May 20. https://www.theguardian.com/technology/2016/ may/20/elizabeth-warren-uber-lyft-gig-economyworkers [Accessed 11 June, 2019].

Wood, A.J. (2016). 'Flexible scheduling, degradation of job quality and barriers to collective voice', Human Relations, 69: 10 1989-2010. 